\title{
THE STRUCTURE OF ROEMREFIDINE
}

\section{S. T. Akramov and S. Yu. Yunusov}

Khimiya Prirodnykh Soedinenii, Vol. 4, No. 3, pp. 199-200, 1968

It has previously been reported that a number of bases have been isolated from the combined alkaloids of Roemeria refracta $[1-5]$.

Continuing the separation of the readily water-soluble fraction of the mixed bases obtained from $470 \mathrm{~kg}$ of the plant, we have isolated $140 \mathrm{mg}$ of crystals with $\mathrm{mp} 223-224^{\circ} \mathrm{C}$ (from aqueous methanol).

From its properties the base is a new one, and we have called it roemrefidine. The UV spectrum has maxima in the 270 and $315 \mathrm{~m} \mu$ regions ( $\log \varepsilon 4.26$ and 3.73 , respectively). The spectra of roemrefidine is similar to that of michepressine iodide [6]. Roemrefidine does not contain methoxy, hydroxy, or carbonyl groups and gives positive reactions for a methylenedioxy group with chromotropic, gallic, and phloroglucinol sulfuric acids. A comparison of the IR and UV spectra of this substance and of $l$-isoroemerine methiodide $[2,3]$ have shown that they are completely identical. A mixture with $l$-isoroemerine methiodide likewise gave no depression of the melting point.

Roemrefidine has been isolated in the form of the iodide and is the quaternary form of the $l$-isoroemerine

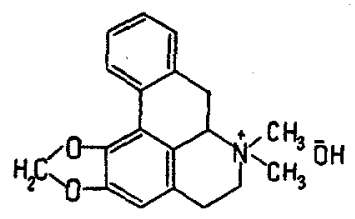

\section{REFERENCES}

1. S. Yu. Yunusov, R. A. Konovalova, and A. P. Orekhov, ZhOKh, 9, 1356, 1939.

2. S. Yu. Yunusov, V. A. Mnatsakanyan, and S. T. Akramov, DAN UzSSR, no. 8, 43, 1961.

3. S. Yu. Yunusov, V. A. Mnatsakanyan, and S. T. Akramov, Izv. AN SSSR, ser. khim., 3, 502, 1965.

4. M. S. Yunusov, S. T. Akramov, and S. Yu. Yunusov, DAN UzSSR, no. 5, 38, 1966.

5. M. S. Yunusov, S. T. Akramov, and S. Yu. Yunusov, KhPS [Chemistry of Natural Compounds], 3, 68, 1967. 6. W. Sangster and L. Stuart, Chem. Rev., 65, 1, 69, 1965.

9 January 1968 Institute of the Chemistry of Plant Substances AS UzSSR

UDC 547.944/945

\section{ALKALOIDS OF THE ROOTS OF THALICTRUM FLAVUM}

Z. F. Ismailov, K. L. Lutfullin, and S. Yu. Yunusov

Khimiya Prirodnykh Soedinenii, Vol. 4, No. 3, p. 200, 1968

The roots of Th. flavum L. collected in the period of vigorous growth of the plant, 20-25 May 1962 in the Chon-Kernin valley, Kirgiz SSR, were extracted with chloroform, and 1.55\% of total alkaloids was isolated. From the chloroform fraction of the mixture of bases, $0.3 \%$ of berberine has been obtained in the form of the chloride [1].

The ethereal fraction of the total alkaloids was treated with methanol. Greenish needle-like crystals of an optically inactive phenolic base with $\mathrm{mp} 133-135^{\circ} \mathrm{C}$ (decomp) were formed. Its IR spectrum: $\lambda_{\mathrm{max}} 236,264,314$, $338 \mathrm{~m} \mu(\log \varepsilon 4.36,4.56,4.12,3.72)$.

The IR spectrum of the base has absorption bands at $1722 \mathrm{~cm}^{-1}$ (carbonyl), 3400 (hydroxyl), 1277, 1230 (methoxy1), and $1040 \mathrm{~cm}^{-1}$ (methylenedioxy group). The properties of this base are very similar to those of thalicsine [2] and it is apparently new.

The mother liquors were separated into phenolic and nonphenolic fractions. The mixture of nonphenolic bases 